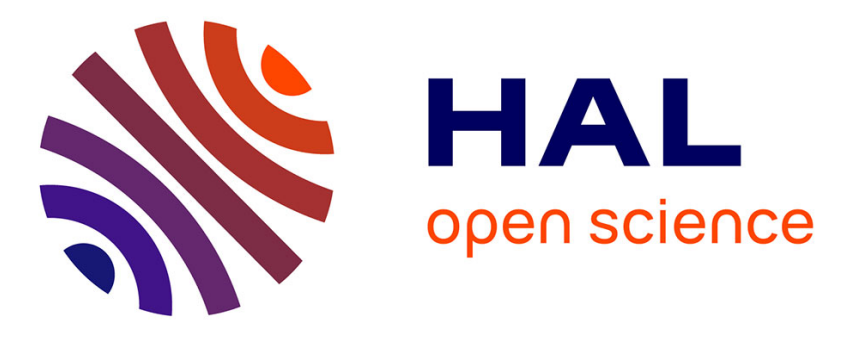

\title{
Cooperative learning in science: Follow-up from primary to high school
}

\author{
Allen Thurston, Keith J Topping, Andrew Tolmie, Donald Christie, Eleni \\ Karagiannidou, Pauline Murray
}

\section{- To cite this version:}

Allen Thurston, Keith J Topping, Andrew Tolmie, Donald Christie, Eleni Karagiannidou, et al.. Cooperative learning in science: Follow-up from primary to high school. International Journal of Science Education, 2010, 32 (04), pp.501-522. 10.1080/09500690902721673 . hal-00567815

\section{HAL Id: hal-00567815 https://hal.science/hal-00567815}

Submitted on 22 Feb 2011

HAL is a multi-disciplinary open access archive for the deposit and dissemination of scientific research documents, whether they are published or not. The documents may come from teaching and research institutions in France or abroad, or from public or private research centers.
L'archive ouverte pluridisciplinaire HAL, est destinée au dépôt et à la diffusion de documents scientifiques de niveau recherche, publiés ou non, émanant des établissements d'enseignement et de recherche français ou étrangers, des laboratoires publics ou privés. 


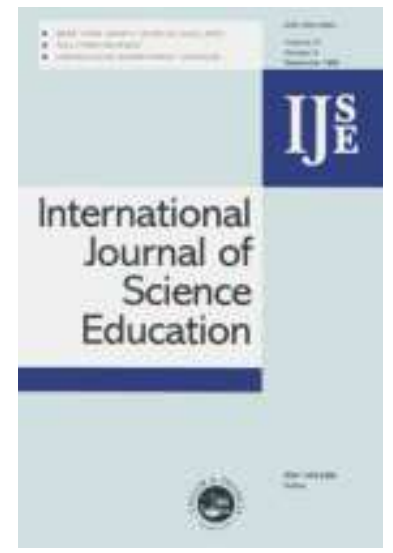

\section{Cooperative learning in science: Follow-up from primary to high school}

\begin{tabular}{|r|l|}
\hline Journal: & International Journal of Science Education \\
\hline Manuscript ID: & TSED-2008-0117.R1 \\
\hline Manuscript Type: & Research Paper \\
\hline Keywords: & $\begin{array}{l}\text { cooperative learning, primary school, secondary school, science } \\
\text { education }\end{array}$ \\
\hline Keywords (user): & cooperative learning, primary school, secondary school \\
\hline \multicolumn{2}{|l}{} \\
\hline
\end{tabular}

\section{$\checkmark$ ScholaroNE}

URL: http://mc.manuscriptcentral.com/tsed Email: ijse_editor@hotmail.co.uk 
Cooperative learning in science

Cooperative learning in science: Follow-up from primary to high school

\begin{abstract}
This paper reports a two year longitudinal study of the effects of cooperative learning on science attainment, attitudes towards science and social connectedness during transition from primary to high school. A previous project on cooperative learning in primary schools observed gains in science understanding and in social aspects of school life. This project followed 204 children involved in the previous project and 440 comparison children who were not as they undertook transition from 24 primary to 16 high schools. Cognitive, affective and social gains observed in the original project survived transition. The implications improving the effectiveness of school transition by using cooperative learning initiatives are explored. Possibilities for future research and the implications for practice and policy are discussed.
\end{abstract}


Cooperative learning in science

\section{Introduction}

Cooperative learning in science

Groupwork and cooperative learning in science education are already incorporated into the pedagogical practices in many countries (Howe et al, 2007). Groupwork in science often forms part of practitioner guides (e.g. Harlen \& Qualter, 2004; Sharp, Peacock, Johnsey, Simon \& Smith, 2007; Topping \& Thurston, 2005). Within Scotland groupwork has reached the level of national policy in the new 'Curriculum for Excellence' science outcomes which specifically identify the need for group discussion in effective learning (Scottish Government, 2008). The effectiveness of groupwork and cooperative learning strategies in science have been widely reported over a number of years. Basili and Sanford (1991) reported that in a sample of 62 students studying in a community college, use of cooperative groupwork in chemistry resulted in students holding fewer misconceptions than those taught by direct tuition. Howe et al (2007) reported that in a sample of primary school pupils drawn from 24 classes that groupwork, and the discussion it facilitated, played a critical role in enhancing the learning of pupils in two science topics in rural and urban settings in the UK. However, there is an absence of literature regarding the longevity of such gains, and no previous literature that looks at whether such gains survive transition after a change of school. 
Cooperative learning in science

The Group Work Transition (GWT) project built on and extended on a previous research project sponsored under the Economic and Social Research Council (ESRC) Teaching and Learning Research Project (TLRP). It was designed as a longitudinal follow-up to the Scottish extension project: "Supporting Group Work in Scottish Schools: Age and Urban/Rural Divide" (SCOTSPRING). The original project found evidence of gains in science attainment and social connectedness as a result of the intervention. Therefore, the project explored the effects of transitions (moving from one school context to another) and transfers (the ability of pupils to use previous learning, attitudes and skills in the new educational context) as the original study group moved school in urban and rural geographical locations. Both transition and transfer are reported as being critical influences on a child's development and schooling.

Transition between schools

It has long been recognised that movement from elementary/primary to middle/high school can result in decreased academic attainment and motivation after transition (e.g. Finger \& Silverman, 1966). In a sample of 933 pupils, decreased attainment scores and decreased levels of motivation were observed at transitions from elementary to middle and middle to high school in a sample drawn from Ogden Utah City School District, , USA (Barber \& Olsen, 2004). Significant declines in science attainment scores were evident after transition for a sample of 225 twelve-year-old students drawn from an urban school in Chicago, Illinois, USA (Petersen \& Crockett, 1985). The falls in academic performance were related to decreased self-concept as a learner, decreased 
Cooperative learning in science

self concept in individual subjects and a mismatch between the development needs of young adolescents at the end of elementary school and the environment of the middle school (Mullins \& Irvin, 2000).

At a time when friendships and the peer group are becoming increasingly important in the development of the adolescent, the transition between schools often serves to disrupt, alter or sever them (Mizelle \& Irvin, 2000). Barber and Olsen (2004) reported increased loneliness and depression and decreased initiatives with peers after transition to middle school for a sample of 933 twelve-year-old pupils. Similar findings were reported in a two year longitudinal study of 143 ten-eleven-year-old pupils from a school district with an associated population of 100,000 people in Midwestern USA (Hirsch \& DuBois, 1992). Peer support prior to transition was inversely correlated to increased psychological symptomatology during the period of school transition from elementary to junior high (although effects lessened over time).

A number of interventions have been reported to promote more effective transition. These include development of shared pedagogy in staff between schools, promoting study skills in students, involving parents in transition, and giving information/ orientation sessions to students (Mizelle, 2005). Mizelle concluded that an effective way to enhance transition was to engage students in positive social relationships with other incoming students. Lindsay (1998) reported an initiative in Kilbourbe High School, Worthington, Ohio, USA that closed the school to all students except new entrants. This resulted in the formation of positive social relationships between new students and 
Cooperative learning in science

decreased levels of anxiety. Facilitating the perpetuation of peer relationships stemming from the previous school setting is also reported to promote effective transition (Carter, Clark, Cushing \& Kennedy, 2005). Peer relationships are reported by students to be a cause of anxiety regarding transition (Arowosafe \& Irvin, 1992). Missing friends from elementary school, having trouble making new friends and not being part of a group were reported as stressors by a sample of eleven-year-old children in New Jersey assessed four weeks after transition to middle school (Elias, Gara \& Ubriaco, 1985).

The role of peer relationships has long been recognised as a buffer as students undergo transition (Hertzog, Morgan, Diamond \& Walker, 1996). Students who had a structured series of peer interactions with older students at transition displayed fewer failing grades and missed fewer days of school than students who did not participate in such a programme (Cognato, 1999). It was also reported that in Cognato's programme female students in particular benefited in socialisation and maintained self-esteem.

Academic performance after transition is influenced by the extent to which previous knowledge can be carried over or transferred successfully to the new school context. For some students this is a major barrier as they enter high school. In a sample of 25,795 students (average age 14.09 years) almost one quarter of students who had good eighth grade attainment results failed at least one subject in ninth grade in the first semester after transition to senior high school high school in Chicago, Illinois, USA (Roderick \& Camburn, 1999). The question remains as to what could promote effective transfer of previous learning at transition. Given that it appears that transfer may not 
Cooperative learning in science

occur automatically for all students at transition, further explorations as to processes that may promote transfer are required.

\section{Transfer theory}

Transfer or generalization of learning can occur over time and space. Transfer can be implicit or explicit. This latter distinction has been termed 'low road' (depending on extensive and varied practice of a skill so that it is automatic) and 'high road' (dependent on the learner's deliberate "mindful abstraction" and subsequent application of general principles) transfer (Perkins \& Salomon, 1987). The latter is akin to what many term 'meta-cognition' - knowledge about one's own cognition and the regulation of that cognition (Simons, 1994). Meta-cognition includes reflection, self-knowledge of strengths and weaknesses, learning strategies and monitoring learning.

Opinions are divided on issues of transfer of learning. In the field of adult learning, strict adherents of theories of "situated learning" (Lave \& Wenger, 1991; Resnick \& Collins, 1994) contend that skills are quite use-specific and are acquired and situated in certain contexts. A more moderate view is that there are specific requirements for transfer to occur - the structure of the activity required in the situation which is the target for transfer must be similar to that in the original situation. Much education actually proceeds on the assumption of transfer (e.g. one subject into another, one year into another, or transition between schools). 
Cooperative learning in science

Gray and Orasanu (1987) reviewed the literature and concluded pessimistically that training has a limited effect in enhancing intellectual performance; skills did not transfer to novel contexts. Niedelman (1991) reviewed the evidence on 'low road' and 'high road' transfer, and did not find research supporting the use of highroad mechanisms to foster transfer of domain-specific knowledge or higher-order thinking. In contrast, Perkins and Salomon (1989) argued that transfer could be obtained when general principles of reasoning were taught together with self-monitoring practices. Campione, Shapiro and Brown (1995) concluded there are multiple manifestations of transfer, ranging from the understanding of domain-specific concepts through the deployment of relatively domaingeneral argumentation strategies.

Sternberg and Frensch (1993) identified that transfer of an item depends upon how it was encoded and organised - and whether a person has the ability to perceive how a task or situation may carry over to other situations. Bransford, Brown and Cocking (1999) reviewed evidence on transfer of learning and concluded that to facilitate transfer, learners must understand when what has been learned can be used. This occurs when learners have conceptual knowledge, mental representations of problems and understanding of the relationships of the components in the overall structure of a problem. In addition learners need to be self-aware and have self-appraisal strategies (i.e. meta-cognition). Pintrich's (1999) review emphasised the role of learner motivation, suggesting that self-regulated learning could be facilitated by adoption of mastery goals (e.g. success in self-improvement and learning) and to some extent by relative ability goals (e.g. competing with others), but can be hindered by the adoption of extrinsic 
Cooperative learning in science

instrumental goals (e.g. getting good grades). Alexander and Murphy (1999) suggested that nurturing transfer requires that teachers used a three-pronged attack (knowledge; strategy; motivational training) that promoted principled understanding.

To promote transfer, Campione, Shapiro and Brown (1995) used collaborative learning (discussion involving students explaining what they were learning to others); knowledge building and transformation (rather than knowledge telling); understanding within domains; reasoning strategies; reflection and meta-cognitive skills. Students taught these showed "impressive degrees of transfer" compared with controls. There have been several successful attempts to teach meta-cognitive strategy and skills (Covington, 1987). Simons (1994) proposed 14 principles for 'Meta-cognitive Instruction', which included:

- centrality of the interaction of cognitive, meta-cognitive and affective components of learning;

- emphasising learning processes (rather than outcomes) and deeper cognitive processing;

- helping students to recognise and practice their learning strategies, reflectivity and self-regulation skills;

- shifting responsibility for learning and its regulation gradually to the students; and building new learning onto students' existing knowledge and conceptions. 
Cooperative learning in science

\section{Urban and rural schooling}

The issue of urban and rural education is important in Scotland. Scotland has a population density of 64 inhabitants per square kilometre (although in much of the highlands the average is 8 inhabitants per square kilometre) (General Register Office for Scotland, 2004). By contrast England has a population density average of 379 inhabitants per square kilometre (Demographia, 2008) and the population densities of France, Germany and Italy are 110, 232 and 193 inhabitants per square kilometre respectively (United Nations World Populations Prospects Report, 2004). Therefore, rural education plays an essential role in the education of many Scottish children. The rural/urban location can have an effect on the pedagogical practices employed by teachers. It was reported that teacher behaviour was different in large and small classes in Norwegian rural schools. Teachers in larger classes exhibited greater control on individual behaviour. This led towards the development of classroom environments dominated by teaching and mediation of knowledge. Smaller rural classrooms tended towards individual and collective freedom. This allowed social constructivist approaches to develop more effectively (Kvalsund, 2004). It was reported that pupils in rural schools in Northern Ireland had more extensive cross age and cross sex peer relationships that pupils in urban schools (Gallacher, 2005). Thurston et al., (2008) reported that teachers in rural settings used more group work and facilitated more classroom discussion as a result. Whilst it might be assumed that transition between schools in rural and urban locations may result in different experiences and outcomes, the research literature in this field is incomplete. 
Cooperative learning in science

\begin{abstract}
Aims
Two interwoven issues are to be addressed in this paper. Firstly, the paper will explore whether pupils were able to transfer gains from the original project to their new high school setting. Secondly, if there is effective transition, what aspects of the original project may be responsible for promoting this, especially in relation to the differential effects of undergoing transition from either an urban or rural primary school setting. Science attainment, attitudes towards science and the social connectedness of followup pupils will be assessed and compared to that of children not involved in the original project. The research aimed to:
\end{abstract}

- track pupils who had been involved in the original groupwork project after they had undergone transition from primary to high school (follow-up pupils),

- explore whether gains in attainment in science, attitudes towards science and range and nature of social connections persisted over time and were still present after transition,

- explore whether transition resulted in differential effects for pupils in rural and urban contexts,

- identify pupils with whom comparisons could be made - those who had not been involved in the original study (non follow-up comparator pupils). 
Cooperative learning in science

\title{
Research Questions
}

The project had the following research questions:

1 In the two academic years after involvement in the original research, did gains in science understanding, attitudes and social relationships transfer and endure despite the changed context?

2 If gains did endure and transfer occurred, what relevant differences if any were evident between rural and urban schools?

3 Could differences be identified in science attainment, attitudes towards science and the nature of social relationships during science classes after transition to high school between original experimental pupils and comparator pupils?

\author{
Methods \\ Background
}

The Group Work Transition (GWT) project was designed as a longitudinal follow-up to the Scottish extension project: "Supporting Group Work in Scottish Schools: Age and Urban/Rural Divide" (SCOTSPRING) associated to the Phase II project "Improving Effectiveness of Pupils Groups in Classrooms". The project websites can be viewed at www.tlrp.org/proj/phase111/Scot extb.html and www.groupworkscotland.org. The 
Cooperative learning in science

SCOTSPRING project examined the effects of a group work intervention in science on 10-12 year old pupils in rural and urban primary school in Scotland:

In the SCOTSPRING project twenty-four experimental classes were drawn from schools (twelve rural and twelve urban). Pupils in experimental classrooms engaged in general group work skills training and two structured group work projects in science. Important aspects of the work undertaken during the original SCOTSPRING project were that it took place in authentic classrooms and the implementation covered structural features, teacher role, and pupil interaction. SCOTSRPING started with activities for developing generic group skills. These activities began with a continuing professional development session, where teachers were introduced to desired structural features and teacher roles. Subsequently, teachers took their classes through group-based exercises designed to promote skills such as listening, questioning, helping, giving explanations and reaching agreement. In these respects the SCOTSPRING science group work differed significantly from the sort of group work that already exists in schools. The exercises were described in resource packs that the researchers provided, and were introduced during the continuing professional development session. Second, subsequent to skills training, the pupils went through two programmes of science teaching, one addressing evaporation and condensation, and the other addressing forces. Each programme covered key concepts, and required pupils to design investigations. For instance, the forces programme covered the angle, smoothness and height of slopes, and the weight and streamlining of cars as influences on motion, and introduced the concepts of gravity, friction and air resistance. The group tasks 
Cooperative learning in science

incorporated features shown in earlier experimental studies (primarily Howe \& Tolmie, 2003; Howe et al., 1995, 2000; Tolmie, Howe, Mackenzie, \& Greer, 1993) to maximise the chances of pupils proposing ideas, disagreeing, explaining their reasoning, referring back and reaching consensus. In other words, the generic training was designed to promote pupil and teacher confidence and capability to use effective interaction when undertaking group work activities in science. The tasks themselves were designed to support the forms of pupil interaction that previous research had found to be beneficial. The programmes were implemented by teachers using researcher- supplied resources (which had themselves been developed in consultation with teachers), and in each case involved two to three hours of teaching spread over several weeks.

Pupil understanding of evaporation and condensation and forces was tested before and after the programmes, and progress significantly exceeded that made by control pupils who received teaching in the two topic areas, but did not participate in the group skills training or the SCOTSPRING science programmes. Observational data were collected while the programmes were being implemented, and these supported the conclusions that enhanced ability of pupils to use appropriate discourse and dialogue (directly related to the group work communication skills training the pupils received in SCOTSPRING, namely, proposing and explaining explanations of scientific concepts) were good predictors of subsequent gains in attainment. Data from the SCOTSPRING project was analysed with multiple regression analysis to examine the extent to which post-test scores were predicted by the proposition/explanation frequencies and indicated that they predicted post-test score for both evaporation and condensation ( $\beta=$ 
Cooperative learning in science

0.28, $\mathrm{t}=3.10, \mathrm{p}<0.01)$, and force and motion $(\beta=0.29, \mathrm{t}=3.13, \mathrm{p}<0.01)$ (Howe et al., 2007). General science attainment was also assessed using the Performance Indicators in Primary Schools (PIPS) instrument Significant gains in general science attainment were observed in the experimental classes. Significant changes in observed group work behaviours were evident in both urban and rural classes. Changes in group work behaviour were correlated to increased general and specific science attainment. The increases in the number of ideas suggested by children were significantly correlated to increases in science attainment in the urban condition $(r=0.557, n=37, p<0.001)$. Increases in offering explanations were correlated to increases in science attainment in the rural condition $(r=0.465, n=40, p<0.01)$ (Thurston et al., 2008). Therefore data from the SCOTSRPING research strongly indicated that increases in science attainment were significantly related to group work behaviours that improved during the intervention.

Other findings of the research were:

1 In achievement gains, both urban and rural classes demonstrated measurable gains, but urban tended to gain most.

2 In the social domain, rural and urban pupils showed significant gains in the number of relationships they reported. Urban pupils showed greatest growth on this measure, but they started the project reporting a lower number of connections to other pupils.

3 There were positive changes over time in quality of pupil-to-pupil interactions in the classroom (pupils became more likely to be engaged in conversations that would 
Cooperative learning in science

promote learning and attainment). These positive changes were associated with better attainment outcomes and were greater in urban classes.

The focus of the current project was to investigate whether any of these gains survived transition from primary to high school.

\section{Recruitment and sampling}

Twelve and thirteen-year-old pupils who had been involved in the SCOTSPRING project and some of their classmates for comparison purposes were tracked as they undertook transition from primary to high school. The progress of the sample was monitored. Target high schools were therefore only those to which the primary project pupils had transferred. A total of 21 relevant high schools were identified. Data was collected from those classes where science teachers expressed their willingness to participate. There were 16 follow-up schools - five schools declined to participate. Data was collected from a total of 630 pupils - 252 follow-up pupils and 378 comparator/control pupils. The detailed composition and average age of the sample set is presented in Table 1.

\section{INSERT TABLE 1 HERE}

This study emerged as a post-hoc development due to the success of the original project. Therefore, it was not possible to identify true control groups as these had not formed an integral part of the design of the original study. This was a limitation of the 
Cooperative learning in science

design of this study and it is acknowledged that results from the study must be viewed within the confines of this constraint.

\section{Measurements}

A battery of assessments was developed or adapted for the testing of both cognitive and affective domains. In the original project the Performance Indicators in Primary School instrument for Primary 7 pupils was used to assess science attainment. This measure was specific to the age and stage of the children at the original time of testing. It would have been inappropriate to use this same measure two years later. Therefore, a new measure that had been widely used in Scottish schools was identified. The new measure was a 21-item assessment in general science derived from the full standard 2002 Assessment of Achievement Programme (AAP) test (scored out of 61). The test covered general science, but excluded items that were connected to the two topics covered by the SCOTSPRING project in primary school science (forces and materials). Nine items asked questions about living things and the processes of life (five multiple choice and four sentence completion), five items were given on energy (three multiple choice and two sentence completion), five items were included about chemical changes (two multiple choice and three sentence completion) and two items were included about the earth in space (one multiple choice and one true/false). The test was reported to have Cronbach's alpha values of between 0.7 and 0.8 when used with 1306 twelve and thirteen year old pupils in Scottish schools during the AAP testing phase of 2002 (Scottish Executive Education Department, 2005). 
Cooperative learning in science

A test was also developed which measured longevity of gains from the previous intervention in the specific science topic of Forces, comprising 29 items (scored out of 37). This was administered to assess enduring knowledge on the topic from the primary project. Cronbach's alpha for test/retest scores of 525 pupils during the original project was 0.66 . Fourteen questions addressed the properties of slopes and cars relevant to speed of rolling. The questions were associated with diagrams, each of which showed a pair of slopes and cars. The pairs varied along one dimension (e.g. high or middle slope), two dimensions (e.g. bumpy or smooth slope, medium or big push), or three dimensions (e.g. high or middle slope, bumpy or smooth slope, pointed- or flat-fronted car). The task with each diagram was to identify which car would roll furthest, and why this would happen (from five options, e.g. 'the car is lighter', 'there is less air resistance'). Twelve further questions focused generally on forces. Definitions were requested for gravity (five options, e.g. 'air pushing down', 'the pull of one object on another'), friction (five options, e.g. 'the rubbing of one surface against another', 'wind blowing against an object') and air resistance (five options, e.g. 'the push of air against an object', 'wind pushing an object along'). Then each force was to be drawn on a diagram, which showed a car on a slope, and explanations were to be given of what the force does (two options, i.e. 'make the car move', 'slow the car down'), and how it works (four options, e.g. 'rubs back against the wheels', 'the air pushes the car down'). The test ended with three questions where, due to combinations of slope and car characteristics, the car could be said to be moving quickly, moving slowly or not moving. 
Cooperative learning in science

Explanations were to be given (five or six options, e.g. 'the car is very heavy', 'there is less air resistance on the car').

Attitudes to Science, a 21-item questionnaire, was used to explore pupils' attitudes towards the school subject of science (Pell \& Jarvis, 2001). Items were slightly modified from the 'what I think of science' scale. This scale was reported by Pell and Jarvis to have good reliability and validity (Cronbach's alpha 0.74 with a group of 116 elevenyear-old pupils). Each of 21 items was scored on a five point Likert scale with only the poles marked as agree and disagree. Children were asked to indicate whether they agreed or disagreed with statements. Half of the items on each sub-scale were worded such that the polarity of the response was reversed.

Finally, as in the ScotSPRinG project, a Sociometric measure was employed to investigate pupils' social relationships and patterns of interaction both inside and outside school. In the SCOTSPRING project the instrument showed reasonable reliability when used with 575 ten to twelve-year-old pupils (Cronbach's alpha 0.69). 'People in your Class' was presented in the form of a matrix and asked respondents to consider four key context questions (columns) regarding their relationships with all other members of their science class (already printed in rows on the instrument). 'People in your group' asked the pupils to undertake the same task, but only for the science work group (with the names of those in their science work group already printed on the instrument). Both instruments asked the pupils to mark all those pupils in their class / group that they: 
Cooperative learning in science

- Worked with regularly in their class/group

- Liked working with in science

- Liked spending time with at break time

- Liked seeing out of school

\title{
Procedure
}

\begin{abstract}
All measures were administered by two research assistants. Each researcher worked to a pre-determined administration protocol within schools in a defined geographical area centred around one of two major cities. They administered the tests and measures giving similar instructions and examples of how to complete responses to items and allowing a set time for completion (120 minutes for the total battery of tests administered in two sittings, before and after a 15 minute break). All measures were administered within a three week period in the last two weeks of October to the end of the first week in November. Tests were marked according to predefined marking templates and any anomalous answers discussed within the group for consistency of decision making. Therefore, inter-rater consistency between markers was excellent with them performing at exactly the same level of performance in the pilot marking exercises. No errors in marking were reported during this process. Each researcher collated data onto a predefined data handling template and the two data files were merged after completion.
\end{abstract}


Cooperative learning in science

\section{Results}

In the results section data is only presented for each item where no discrepancies in any item were reported during the marking process. In addition correlation and regressions are reported only when data from all the instruments required to perform such analyses were completed in a satisfactory manner. For this reason it should be noted that degrees of freedom may differ between analyses. Average pre and posttransition cognitive and attitudinal measure scores for follow-up and comparator pupils are presented in Table 2.

\section{INSERT TABLE 2 HERE}

Post-transition follow-up pupils scored higher in the forces test $(F(1,596)=12.28$, $p<0.001)$ than comparator pupils. The advantage in science attainment in the topic of forces that the follow-up pupils originally exhibited (Howe at al., 2007) was still identifiable eighteen months after the initial project ended. The forces attainment scores of the follow-up pupils were not significantly lower than scores obtained for the same pupils at the end of the original project $(F(1,183)=1.636$, ns). No significant differences in post-transition general science attainment were observed between follow-up and comparator populations $(\mathrm{F}(1,354)=0.31$, ns $)$.

Pre-transition one way ANOVA showed there were no significant differences between the rural and urban follow-up pupils in science attainment $(F(1,131)=1.908$, ns $)$ or in the 
Cooperative learning in science

forces test $(F(1,185)=2.11, n s)$. After transition no significant differences were observed between the rural and urban follow-up pupils in either science attainment $(F(1.196)=160.56, n s)$ or the forces test $(F(1,196)=0.016, n s)$. This indicated that pupils in both rural and urban contexts had transferred science knowledge with equal effectiveness.

Follow-up pupils reported more positive attitudes towards science than non follow-up pupils, but differences did not achieve significance $(F(1,457)=0.985, p=n s)$. However, when analysed as separate sub-groups both urban $(F(1,121)=7.143, p<0.01)$ and rural $(F(1,91)=4.29, p<0.05)$ follow-up pupils reported more positive attitudes towards science than comparator pupils. Positive correlations (Pearson's $r$ ) were found between attitudes towards science and post-transition forces test scores $(r=0.329, p>0.001$, $n=155)$ and science attainment $(r=0.283, p>0.001, n=155)$.

Data from the sociometric instrument are presented in Table 3. Significant regression relationships were evident between percentages of pupils in the science work-groups reported as 'liked seeing out of school' and post-transition science attainment $(\beta=0.163$, $\left.\mathrm{t}(457)=3.531, \mathrm{p}<0.0001 ; R^{2}=0.024, \mathrm{~F}(1,457)=4.87, \mathrm{p}<0.0001\right)$, and percentage of pupils from the science work-groups reported as 'liked spending time with at break' and posttransition science attainment $\left(\beta=0.123, \mathrm{t}(456)=2.651, \mathrm{p}<0.01 ; R^{2}=0.013, \mathrm{~F}(1,456)=6.04\right.$, $p<0.01)$. Positive correlations were found between post-transition science attainment and percentage of pupils from the science work-groups that children reported they liked 
Cooperative learning in science

working with in science $(r=0.183, p>0.05, n=167)$, liked spending time with at break $(r=0.188, p>0.05, n=167)$, and liked seeing with out of school $(r=0.170, p>0.05, n=166)$.

There was evidence of transfer of social gains from the original project. The percentage of people from their science work group that pupils reported that they liked to work with in science was predicted by the percentage of their classmates that pupils reported they liked to work with in primary school. Regression analysis indicated that this relationship was linear and significant $\quad\left(\beta=0.349, \quad t(159)=4.698, \quad p<0.0001 ; \quad R^{2}=0.122, F\right.$ $(1,159)=22.068, p<0.0001)$. Those pupils who showed the greatest ability to form positive work relationships at the end of the original project still exhibited this ability after transition.

Pupils from follow-up groups reported higher average percentage of work and play relationships than comparator pupils (Table 3). However, these differences were not significant. Pupils from both follow-up and comparator groups showed a stronger inclination to focus relationships on peers within their science work-group rather than in their class. For follow-up pupils the percentage of the science work-group was greater than the percentage of the class that they reported they liked working with in science $(\mathrm{t}=-8.933, \mathrm{df}=167, \mathrm{p}<0.0001$, one tailed); liked spending time with at break $(\mathrm{t}=-8.207$, $d f=167, p<0.0001$, one tailed); and liked spending time with out of school $(t=-7.706$, $d f=166, p<0.0001$, one tailed). For comparator pupils similar patterns were observed. The percentage of the science work-group was greater than the percentage of the class that they reported they liked working with in science $(t=-14.129, \mathrm{df}=313, \mathrm{p}<0.0001$, one 
Cooperative learning in science

tailed); liked spending time with at break ( $\mathrm{t}=-12.357, \mathrm{df}=313, \mathrm{p}<0.0001$, one tailed); and liked spending time with out of school $(t=-11.956$. $d f=313, p<0.0001$, one tailed).

\section{INSERT TABLE 3 HERE}

In summary results indicated that there was evidence of transfer of gains (forces test attainment results) by pupils involved in the original project. They were significantly advantaged in the science topic of forces compared to the comparator pupils (despite general science attainment being similar in both follow-up and comparator populations). Pupils from rural and urban primary school settings showed similar patterns of transfer. In general follow-up pupils reported more positive attitudes towards science than comparator pupils. These differences reached significant levels when analysed in the rural and urban populations independently. Social and attitudinal aspects to learning and peer support were significant and important predictors of post transition attainment. Those pupils who demonstrated an ability to develop social connections to their peers in primary school were the same group who were able to establish effective peer relationships in high school. Evidence of transfer was thus observed in the follow-up population.

\section{Discussion}

The original project appeared to have a two-fold effect. Firstly, it appeared that gains in learning and social skills observed in the SCOTSPRING project could be transferred 
Cooperative learning in science

and effectively used after transition. Attainment gains that accrued during the original study persisted over time, and gains were still observable in the experimental group eighteen months after the original cooperative learning project. Campione et al. (1995) concluded that cooperative learning could be a critical factor that dictates whether learning can subsequently be transferred. This may be due to the way that learning is encoded during the cooperative learning processes. The important aspect of the encoding process when undertaking cooperative group work is that learning may proceed with knowledge on how the learning relates to prior learning, learner selfawareness about what they are doing (self-regulation of learning being promoted and facilitated by immediate feedback from peers) and that talking about thinking is possible as the group works on a problem. Thus learning may be encoded with metacognition.

It had previously been reported that when mathematics was taught using cooperative learning and metacognitive strategies to 384 twelve and thirteen-year-old pupils the possibility of knowledge transfer to other contexts was enhanced (Kramarski \& Mevarech, 2003). Similar findings were reported for 206 nine and ten-year-old children undertaking cooperative learning tasks, which were reported to promote metacognitive awareness about learning (Meloth \& Deering, 1994). A possible mechanism for this may be that cooperative groupwork enables and facilitates a greater volume of engaged and successful practice, leading to consolidation, fluency and automaticity of core skills (see Figure 1). As this occurs, group members give feedback to each other, implicitly and/or explicitly. The quantity and immediacy of feedback to the learner is likely to be greater than that which could be generated by teacher intervention alone. Explicit reinforcement 
Cooperative learning in science

might stem from within the groupwork or beyond it, by way of verbal and/or non-verbal praise, social acknowledgement and status, or official accreditation. As the learning relationship develops, group members should begin to become more consciously aware of what is happening in their learning interaction, and consequently more able to monitor and regulate the effectiveness of their own learning strategies. This development into fully conscious explicit and strategic meta-cognition is likely to encode learning in such a way that might facilitate later transfer. It should also make group members more confident that they can achieve even more, and that success is the result of their own efforts.

\section{INSERT FIGURE 1 HERE}

It might be that each stage of the peer learning process feeds back into the originating sub-processes - forming a continuous iterative process and a virtuous circle that promotes metacognition as learning is encoded. If as cooperative groupwork proceeds information is iteratively encoded with knowledge, understanding and self-regulation of that learning (i.e. metacognition), then this would explain why learning encoded in such circumstances can be transferred to new contexts (Campione et al., 1995; Bransford et al., 1999; Sternberg \& Frensch, 1993). Whilst there was evidence that the level of productive feedback and reinforcement given to group members in the original project was positively influenced by the intervention (Howe et al, 2007, Thurston et al. 2008), further work is required to explore this process and possible mechanisms more fully. 
Cooperative learning in science

Data indicated pupils undergoing transition in rural and urban contexts transferred cognitive gains equally. Previous research reported that rural pupils fared less well at school transition as they moved from smaller, friendlier school settings to larger, more impersonal school settings (Barber \& Olsen, 2004). This finding is not consonant with that. This might lead to the re-examination of previous assumptions regarding school transition in the rural context.

Secondly, the social relationships that could be developed by pupils after transition were significantly related to higher post-transition attainment. A significant finding of the original project had been increased ability to develop and maintain more peer relationships. Transfer of previous learning was directly related to the scope and extent of work based relationships after transition. There may be some support for the hypothesis that social gains from the original project had the potential to act as buffers to the effects of transition and helped promote transfer. A significant finding of the original project was the increased ability of pupils to form positive work relationships with classmates after training (Thurston, Topping, Tolmie \& Christie, 2008). Peer relationships formed in work based settings (i.e. peer relationships formed with pupils with whom respondents worked with in science, as opposed to those whom they were just in the same science class as) dominated the nature of relationships formed in the classroom, the playground and outside of school for both follow-up and comparator pupils. This finding is in line with other researchers who have reported the important buffering effects of peer relationships in students undergoing transition (Hertzog, 
Cooperative learning in science

Morgan, Diamond \& Walker, 1996). At a time when friendships and the peer group become important in the development of students, transition between schools can disrupt, alter or sever existing relationships (Erikson, 1980, Mizelle \& Irvin, 2000). The social advantage after transition was significantly related to the observed science attainment scores. This suggests that ability to develop effective work relationships in the science classroom may provide a buffering effect against dips in science attainment after transition. These findings are consistent with those of other studies and add weight to literature surrounding the importance of peer relationships at school transitions (Hirsch \& DuBois, 1992; Cognato, 1999).

\section{Conclusion}

The data presented in this research indicates that using co-operative learning strategies in science may allow transfer of knowledge and skills acquired to new contexts. Prior learning undertaken during the previous project in the science topic of forces was still evident and appeared stable after transition to high school. Follow-up pupils were advantaged in respect of their knowledge in this topic when judged against comparator pupils. Pupils from both rural and urban school contexts transferred learning successfully at transition. Follow-up pupils reported more positive attitudes towards science than comparator pupils from similar geographical contexts. Peer relationships appeared to play an important role in promoting effective transition and transfer for both follow-up and comparator pupils. Pupils tended to focus peer relationships on pupils with whom they worked, rather than more generally with the class. 
Cooperative learning in science

It may be incumbent upon schools to adopt appropriate pedagogical strategies before transition. Such pedagogical strategies would include providing specific development work with pupils on social and communication skills training. When undertaking peer learning activities then clear protocols for interaction, assigning roles within the group and ensuring that teacher feedback focuses on both effective group work issues as well as cognitive issues would appear to maximise the changes of the peer learning having a positive and lasting outcomes. If peer learning constructed along the lines of the original SCOTSPRING design is used as a context for the delivery of work prior to transition then this may lead to more effective transfer of learning as pupils undergo transition. In turn this may have the potential to minimise falls in science attainment. It appears to be important that schools make effective use of peer-support mechanisms prior to transition. Pupils from the SCOTSPRING project appeared to be more able than the comparator group to make and foster new working relationships with their new classmates. Therefore, it may be reasonable to construct a hypothesis that some of the advantages that accrued for pupils from the original social and communication skills training may still be evident in the follow-up sample. Some form of training opportunities for pupils on how to develop and maintain peer relationships may be useful to them and aid pupils to transfer cognitive structures, promote positive affective dispositions towards working and generate effective social skills that help pupils develop working relationships in the new school environment. The results presented in this study, and the previous SCOTSPRING study indicates that effective training of this nature may 
Cooperative learning in science

include both social skills and communication skills. These social and communication skills can be summarised as:

1. Taking turns at talking

2. Active listening to others in the group

3. Asking and answering questions

4. Making and asking for suggestions from all group members

5. Expressing and requesting ideas and opinions from all group members

6. Brainstorming suggestions, ideas and opinions together

7. Giving and asking for help from group members and from the teacher

8. Giving and asking for explanations from group members and from the teacher

9. Explaining and evaluating ideas

10. Making group decisions and coming to consensus

11. Summarising conversations to fully represent the ideas of all group members

12. Using persuasive talk to help others members of the group reshape their thinking

There is evidence from the original project that when training for pupils included items such as those listed above then effective use of talk during group discussions was enhanced. This resulted in the SCOTSPRING post intervention observations (as compared to pre intervention observations) indicting increased levels of children suggesting ideas or courses of action $(F(1,129)=25.03, P<0.0001)$, offering explanations to propositions $(F(1,129)=4.29, p<0.05)$, and telling someone to carry out an action $(F(1,129)=19.42, p<0.0001)$ (Thurston, Christie, Howe, Tomie \& Topping, 2008). In the 
Cooperative learning in science

SCORSPRING project it was reported that the frequency of children suggesting ideas and courses of actions and telling someone to carry out an action were predictors posttest scores in science tests in evaporation and condensation $(\beta=0.28, t=3.10, p<0.01)$ and forces and motion $(\beta=0.29, t=3.13, p<0.01)$ (Howe, Tolmie, Thurston, Topping, Christie, Livingston et al, 2007). Qualitative data from teacher questionnaires indicated that teachers involved in the original project reported that there was increased social skills in children and increased social inclusion within the class. They reported that 'Children who might have felt 'alone' in class activities were made to 'belong' in a group situation' and that 'Some 'rocky' children found that the group discussion work enabled them to do well, and as a result feel great' (Thurston et al, 2008). As these original test score gains, and the social gains detected and reported by teacher participants, were still evident in the sample of follow-up children then this would suggest that the SCORSPRING intervention had a positive and lasting effect on these pupils. This may indicate that interventions that are similar in nature, may have the potential to work in other contexts.

The opportunities that co-operative learning affords are not limited to science. Many other initiatives in cooperative learning are reported in other curriculum areas such as reading (e.g., Duran \& Monereo, 2005) and maths (e.g., Topping, Kearney, McGee \& Pugh, 2004). Further research may wish to establish whether transfer of learning during transition can be promoted in other curriculum areas by co-operative learning. In addition further empirical testing of the model presented in Figure 1 may explore the links between cooperative learning and its association with metacognition. This would 
Cooperative learning in science

allow full exploration of the most effective strategies for pupils to encode information with concomitant metacognition in such as way that may promote later transfer.

\title{
Acknowledgement
}

To be inserted.

\section{References}

\begin{abstract}
Alexander, P. A. \& Murphy, P. K. (1999). Nurturing the seeds of transfer: A domainspecific perspective. International Journal of Educational Research, 31(7), 561-576.

Arowosafe, D.S. \& Irvin, J.L. (1992). Transition to a middle level school: What kids say. Middle School Journal, 24(2), 15-19.

Barber, B.K. \& Olsen, J.A. (2004). Assessing the transitions to middle and high school. Journal of Adolescent Research, 19(1), 3-30.

Basili, P. A. \& Sanford, J. P. (1991). Conceptual change strategies and cooperative group work in chemistry. Journal of Research in Science Teaching, 28(4), 293-304.

Bransford, J.D., Brown, A.L., \& Cocking, R.R. (Eds.) (1999). How people learn: Brain, mind, experience and school. Washington DC: National Academy Press.

Campione, J.C., Shapiro, A.M., \& Brown, A.L. (1995). Forms of transfer in a community of learners: Flexible learning and understanding. In McKeough, A., Lupart, J., \& Marini, A. (Eds.) Teaching for transfer: Fostering generalization in learning (pp 3568). Mahwah, NJ: Lawrence Erlbaum Associates.
\end{abstract}


Cooperative learning in science

Carter, E.W., Clark, N.M., Cushing, L.S. \& Kennedy, C.H. (2005). Moving from elementary to middle school: Supporting a smooth transition for students with severe disabilities. Teaching Exceptional Children, 37(3), 8-14.

Cognato, C.A. (1999) Cited In Mizelle, N.B. \& Irvin, J.L. (2000). Transition from middle school to high school. Middle School Journal, 31(5), 57-61.

Covington, M.V. (1987). Instruction in problem-solving planning. In Friedman, S.L., Scholnick E.K., \& Cocking, R.R. (Eds.) Blueprints for thinking: The role of planning in cognitive development (pp 469-511). Cambridge and New York: Cambridge University Press.

Demographia (2008). England local authorities: Ranked by population density. Available at www.demographia.com/db-englad.htm (16th April 2008).

Duran, D. \& Monereo, C.(2005).Styles and sequence of cooperative interaction in fixed and reciprocal peer tutoring, Learning \& Instruction, 15, 179-199.

Elias, M.J., Gara, M. \& Ubriaco, M. (1985). Sources of stress and support in children's transition to middle school: An empirical analysis. Journal of Clinical Child Psychology, 14(2), 112-118.

Erikson, E. (1980). Identity and the life cycle. London: Norton.

Finger, J.A. \& Silverman, M. (1966). Changes in academic performance in the junior high school. Personal and Guidance Journal, 45, 157-164.

Gallacher, T. (2005) Small rural schools in Northern Ireland. A policy discussion document for the Rural Community Network. Available at: ruralcommunitynetwork.unite.net/files/pdf/RCN\%20Small\%20schools.pdf $\left(25^{\text {th }}\right.$ May 2005). 
Cooperative learning in science

General Register Office for Scotland (2004). 2001 census results Available at: www.groscotland.gov.uk/grosweb/grosweb.nsf/pages/censushm (20 ${ }^{\text {th }}$ November 2004).

Gray, W.D. \& Orasanu, J.M. (1987). Transfer of cognitive skills. In Cormier, S.M. \&

Hagman, J.D. (Eds.) Transfer of learning: Contemporary research and applications (pp 183-215). San Diego: Academic Press Inc.

Harlen, W. \& Qualter, A. (2004). The teaching of science in primary schools $\left(4^{\text {th }}\right.$ ed). London: David Fulton.

Hertzog, C.J., Morgan, P.L., Diamond, P.A. \& Walker, M.J. (1996). Transition to high school: A look at students' perceptions. Becoming, 7(2), 6-8.

Hirsch, B.J. \& Dubois, D.L. (1992). The relation of peer social support and psychological symptomatology during the transition to junior high school: A two-year longitudinal analysis. American Journal of Community Psychology, 20(3), 333-347.

Howe, C. J., \& Tolmie, A. (2003). Group work in primary school science: discussion, consensus and guidance from experts. International Journal of Educational Research, 39, 51-72.

Howe, C. J., Tolmie, A., Greer, K., \& Mackenzie, M. (1995). Peer collaboration and conceptual growth in physics: task influences on children's understanding of heating and cooling. Cognition and Instruction, 13, 483-503.

Howe, C. J., Tolmie, A., Duchak-Tanner, V., \& Rattray, C. (2000). Hypothesis testing in science: group consensus and the acquisition of conceptual and procedural knowledge. Learning and Instruction, 10, 361-391. 
Cooperative learning in science

Howe, C.J., Tolmie, A., Thurston, A., Topping, K.J., Christie, D., Livingston, K. et al., (2007). Group work in elementary science: Organisational principles for supporting pupil learning. Learning \& Instruction, 17(5), 549-563.

Kvalsund, R. (2004) Schools as environments for social learning-shaping mechanisms? Comparisons of smaller and larger rural schools in Norway, Scandanavian Journal of Educational Research, 47(4), 347-371.

Lave, J. \& Wenger, E. (1991). Situated learning: Legitimate peripheral participation. Cambridge \& New York: Cambridge University Press.

Lindsay, D. (1998). Middle-level to high-school transition. Education Digest, 63(6), 6274.

Kramarski, B. \& Mevarech, Z.R. (2003). Enhancing mathematical reasoning in the classroom: The effects of cooperative learning and metacognitive training. American Educational Research Journal, 40(1), 281-310.

Meloth, M.S. \& Deering, P.D. (1994). Task talk and task awareness under different cooperative learning conditions. American Educational Research Journal, 31(1), 138-165.

Mizelle, N.B. (2005). Moving out of middle school. Educational Leadership. 62(7), 5660.

Mizelle, N.B. \& Irvin, J.L. (2000). Transition from middle school to high school. Middle School Journal, 31(5), 57-61.

Mullins, E.R. \& Irvin, J.L. (2000). Transition into middle school. Middle School Journal, 31(3), 57-60. 
Cooperative learning in science

Niedelman, M. (1991). Problem solving and transfer. Journal of Learning Disabilities, 24(6), 322-329.

Pell, T. \& Jarvis, T. (2001). Developing attitude to science scales for use with children of ages from five to eleven years. International Journal of Science Education, 23(8), $847-862$.

Perkins, D.N. \& Salomon, G. (1987). Transfer and teaching thinking. In Perkins, D.N., Lochhead, J., \& Bishop, J. (Eds.) Thinking: The second international conference. Hillsdale, NJ: Lawrence Erlbaum.

Perkins, D.N. \& Salomon, G. (1989). Are cognitive skills context-bound? Educational Researcher, 18(10), 16-25.

Petersen, A.C. \& Crockett, L. (1985). Pubertal timing and grade effects on adjustment. Journal of Youth and Adolescence, 14, 191-206.

Pintrich, P.R. (1999). The role of motivation in promoting and sustaining self-regulated learning. International Journal of Educational Research, 31(6), 459-470.

Resnick, L. \& Collins, A. (1994). Cognition and learning. In Husen, T. \& Postlethwaite, T. (Eds.) The international encyclopaedia of education, 2nd edition, volume 2 (pp 835-38). Oxford: Elsevier/Pergamon.

Roderick, M. \& Camburn, E. (1999). Risk and recovery from course failure in the early years of high school. American Educational Research Journal, 36(2), 303-343.

Scottish Executive Educations Department (2005). Assessment of achievement programme: Sixth survey of science 2003. Edinburgh, UK: Scottish Executive Education Department. 
Cooperative learning in science

Scottish Government (2008) Draft Science Outcomes: Curriculum for Excellence.

Available at

www.curriculumforexcellencescotland.gov.uk/Images/science outcomesv2 tcm4-

443199.pdf (16th April 2008).

Sharp, J., Peacock, G., Johnsey, R., Simon, S. \& Smith, R. (2000). Achieving QTS:

Primary science teaching theory and practice $\left(3^{\text {rd }}\right.$ ed). Exeter, UK: Learning Matters.

Simons, P.R.J. (1994). Teaching and testing for metacognitive strategies. In Husen, T., \& Postlethwaite, T. (Eds.) The international encyclopaedia of education, $2^{\text {nd }}$ edition, volume 7 (pp 3788-92). Oxford: Elsevier/Pergamon.

Sternberg, R.J. \& Frensch, P.A. (1993). Mechanisms of transfer. In Detterman, D.K. \& Sternberg, R.J. (Eds.) Transfer on trial: Intelligence, cognition and instruction (pp 25-38). Norwood, NJ: Ablex.

Thurston, A., Christie, D., Howe, C.J., Tolmie, A. \& Topping, K.J. (2008). Effects of continuing professional development on group work practices in Scottish primary schools. Journal of In-service Education, 34(3), 263-282.

Thurston, A., Topping, K.J., Christie, D., Donaldson, C., Howe, C.J., Jessiman, E. et al., (2008). Effects of group work training on science attainment in rural and urban schools. Research in Science \& Technology Education, 26(1), 31-45.

Thurston, A., Topping, K.J., Tolmie, A. \& Christie, D. (2008). Effect of cooperative learning on cognitive/affective factors during transition from elementary to high school. Paper presented at American Education Research Association Annual Gathering, New York, March $24^{\text {th }}-28^{\text {th }} 2008$. 
Cooperative learning in science

Tolmie, A., Howe, C. J., Mackenzie, M., \& Greer, K. (1993). Task design as an influence on dialogue and learning: Primary school group work with object flotation. Social Development, 2, 183-201.

Topping, K. J., Kearney, M., McGee, E., \& Pugh, J. (2004). Tutoring in mathematics: A generic method. Mentoring and Tutoring, 12(3), 353-370.

Topping, K.J. \& Thurston, A. (2005). Enjoying science together. Grangemouth, UK: Geoquest.

United Nations World Populations Prospects Report (2004). World population prospects: The 2004 revision analytical report. Available at www.un.org/esa/population/publications/WPP2004/WPP2004 Volume3.htm (16th April 2008). 
Table 1: Composition of the sample used in the study

\begin{tabular}{|l|l|l|l|}
\hline Condition & Sample & Number $n$ & $\begin{array}{l}\text { Average age } \\
\text { (standard deviation) }\end{array}$ \\
\hline Follow-up pupils & male & 118 & $155.78(7.17)$ \\
\cline { 2 - 4 } & female & 134 & $155.06(6.33)$ \\
\hline \multirow{2}{*}{$\begin{array}{l}\text { Comparator/control } \\
\text { pupils }\end{array}$} & male & 182 & $156.30(6.96)$ \\
\cline { 2 - 4 } $\begin{array}{l}\text { Total of both follow- } \\
\text { up and comparator }\end{array}$ & female & 196 & $156.37(6.73)$ \\
\cline { 2 - 4 } pupils & $\begin{array}{l}\text { female } \\
\text { male and female } \\
\text { combined }\end{array}$ & 330 & $156.10(7.04)$ \\
\hline
\end{tabular}


Table 2: Mean pre and post transition cognitive and attitudinal measure scores for follow-up and non follow-up comparison pupils (standard deviation) [n]

\begin{tabular}{|c|c|c|c|c|c|c|}
\hline & \multicolumn{2}{|c|}{ Pre-transition scores } & \multicolumn{3}{|c|}{ Post-transition scores } \\
\hline Condition & $\begin{array}{l}\text { Rural/ } \\
\text { urban } \\
\text { location }\end{array}$ & $\begin{array}{l}\text { Mean } \\
\text { forces } \\
\text { test } \\
\text { score } \\
\text { (out of } \\
37 \text { ) }\end{array}$ & $\begin{array}{l}\text { Mean } \\
\text { science } \\
\text { attainment } \\
\text { test score } \\
\text { (out of } \\
100 \text { ) }\end{array}$ & $\begin{array}{l}\text { Mean } \\
\text { forces } \\
\text { test } \\
\text { score } \\
\text { (out of } \\
37 \text { ) }\end{array}$ & $\begin{array}{l}\text { Mean } \\
\text { science } \\
\text { attainment } \\
\text { test score } \\
\text { (out of } 61 \text { ) }\end{array}$ & $\begin{array}{l}\text { Mean } \\
\text { attitudes } \\
\text { towards } \\
\text { science } \\
\text { (min=21, } \\
\max =105 \text { ) }\end{array}$ \\
\hline \multirow[t]{3}{*}{$\begin{array}{l}\text { Follow-up } \\
\text { pupils }\end{array}$} & Rural & $\begin{array}{c}23.13 \\
(4.71) \\
{[74]}\end{array}$ & $\begin{array}{c}48.98 \\
(9.59) \\
{[48]}\end{array}$ & $\begin{array}{c}23.30 \\
(6.27) \\
{[74]}\end{array}$ & $\begin{array}{c}28.57 \\
(10.09) \\
{[74]}\end{array}$ & $\begin{array}{c}60.241 \\
(11.08) \\
{[58]}\end{array}$ \\
\hline & Urban & $\begin{array}{l}24.11 \\
(4.26) \\
{[123]}\end{array}$ & $\begin{array}{c}46.54 \\
(9.75) \\
{[85]} \\
\end{array}$ & $\begin{array}{l}23.19 \\
(5.24) \\
{[123]} \\
\end{array}$ & $\begin{array}{l}26.81 \\
(9.29) \\
{[123]}\end{array}$ & $\begin{array}{c}60.239 \\
(12.62) \\
{[96]}\end{array}$ \\
\hline & $\begin{array}{l}\text { Whole } \\
\text { sample }\end{array}$ & $\begin{array}{l}23.78 \\
(4.43) \\
{[187]}\end{array}$ & $\begin{array}{l}47.41 \\
(9.73) \\
{[133]}\end{array}$ & $\begin{array}{l}23.23 \\
(5.63) \\
{[197]}\end{array}$ & $\begin{array}{l}27.47 \\
(9.61) \\
{[197]}\end{array}$ & $\begin{array}{c}60.24 \\
(12.02) \\
{[154]}\end{array}$ \\
\hline \multirow{3}{*}{$\begin{array}{l}\text { Non } \\
\text { follow-up } \\
\text { comparator } \\
\text { pupils }\end{array}$} & Rural & - & - & $\begin{array}{c}23.12 \\
(4.87) \\
{[73]}\end{array}$ & $\begin{array}{c}30.27 \\
(9.39) \\
{[74]}\end{array}$ & $\begin{array}{c}57.28 \\
(12.47) \\
{[52]}\end{array}$ \\
\hline & Urban & - & & $\begin{array}{c}21.15 \\
(6.82) \\
{[85]}\end{array}$ & $\begin{array}{c}25.89 \\
(11.31) \\
{[85]}\end{array}$ & $\begin{array}{c}53.85 \\
(12.70) \\
{[59]}\end{array}$ \\
\hline & $\begin{array}{l}\text { Whole } \\
\text { sample }\end{array}$ & - & - & $\begin{array}{l}22.06 \\
(6.06) \\
{[158]}\end{array}$ & $\begin{array}{c}27.92 \\
(10.66) \\
{[158]}\end{array}$ & $\begin{array}{c}55.45 \\
(12.65) \\
{[149]}\end{array}$ \\
\hline
\end{tabular}


Table 3: Social connectedness of follow-up and non follow-up comparison pupils (standard deviation) [n]

\begin{tabular}{|c|c|c|c|c|c|c|}
\hline & \multicolumn{3}{|c|}{$\begin{array}{l}\text { Mean \% of the science work- } \\
\text { group that pupils reported } \\
\text { that they liked: }\end{array}$} & \multicolumn{3}{|c|}{$\begin{array}{l}\text { Mean \% of the science class group } \\
\text { that pupils reported that they liked: }\end{array}$} \\
\hline & $\begin{array}{l}\text { working } \\
\text { with in } \\
\text { science }\end{array}$ & $\begin{array}{l}\text { spending } \\
\text { time with } \\
\text { at break }\end{array}$ & $\begin{array}{l}\text { seeing } \\
\text { out of } \\
\text { school }\end{array}$ & $\begin{array}{l}\text { working } \\
\text { with in } \\
\text { science }\end{array}$ & $\begin{array}{l}\text { spending } \\
\text { time with } \\
\text { at break }\end{array}$ & $\begin{array}{l}\text { seeing out } \\
\text { of school }\end{array}$ \\
\hline $\begin{array}{l}\text { Follow-up } \\
\text { pupils }\end{array}$ & $\begin{array}{c}66.92 \\
(40.78) \\
{[168]}\end{array}$ & $\begin{array}{c}46.80 \\
(39.24) \\
{[168]}\end{array}$ & $\begin{array}{c}36.99 \\
(37.71 \\
{[167]}\end{array}$ & $\begin{array}{c}32.25 \\
(38.69) \\
{[168]}\end{array}$ & $\begin{array}{c}21.08 \\
(29.46) \\
169]\end{array}$ & $\begin{array}{c}14.37 \\
(25.01) \\
{[167]}\end{array}$ \\
\hline $\begin{array}{l}\text { Non follow-up } \\
\text { comparison } \\
\text { pupils }\end{array}$ & $\begin{array}{c}63.25 \\
(42.01) \\
{[314]}\end{array}$ & $\begin{array}{c}43.90 \\
(40.15) \\
{[314]}\end{array}$ & $\begin{array}{l}34.58 \\
(37.18 \\
{[314]}\end{array}$ & $\begin{array}{c}30.53 \\
(22.56) \\
{[314]}\end{array}$ & $\begin{array}{c}18.55 \\
(42.01) \\
{[314]}\end{array}$ & $\begin{array}{c}13.33 \\
(12.61) \\
{[314]}\end{array}$ \\
\hline
\end{tabular}


Figure 1: Peer learning and metacognition

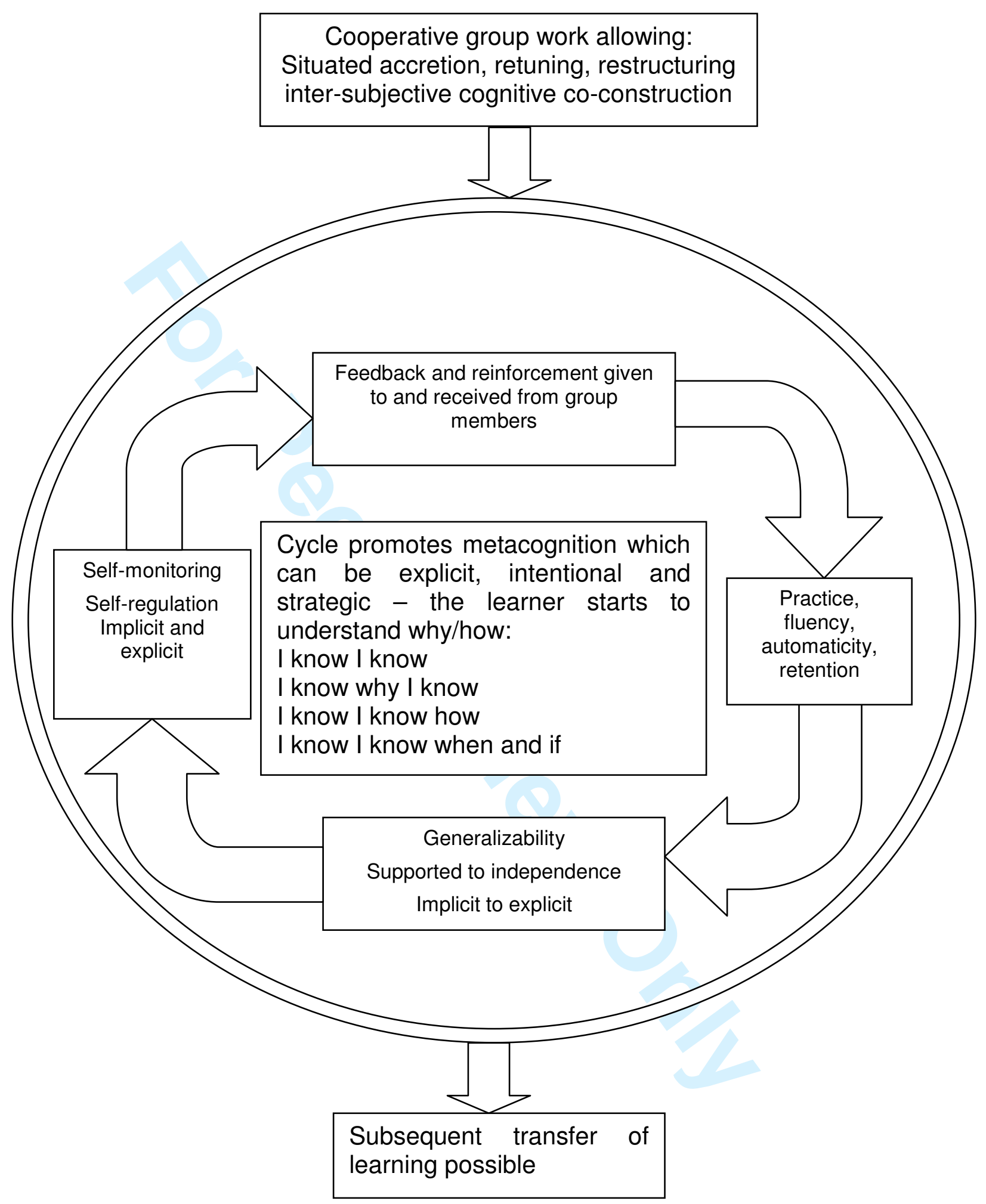

